\title{
THERMAL REgIME ASPECTS WHEN GRINDING RUBBER ROLLS FOR PAPER INDUSTRY
}

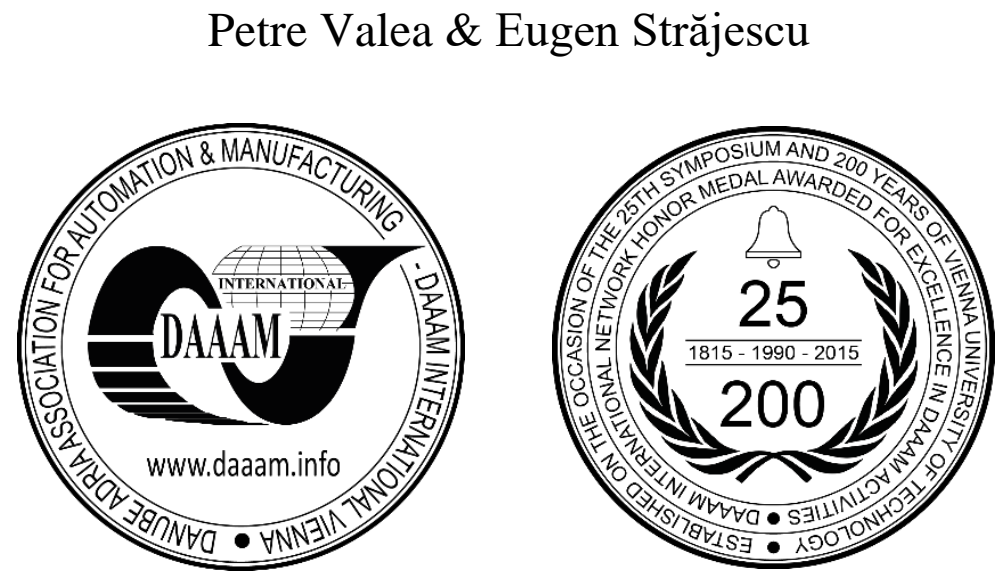

This Publication has to be referred as: Valea, P[etre] \& Strajescu, E[ugen] R[adu] (2017). Thermal Regime Aspects when Grinding Rubber Rolls for Paper Industry, Proceedings of the 28th DAAAM International Symposium, pp.08670874, B. Katalinic (Ed.), Published by DAAAM International, ISBN 978-3-902734-11-2, ISSN 1726-9679, Vienna, Austria

DOI: $10.2507 / 28$ th.daaam.proceedings.121

\begin{abstract}
The paper investigates the thermal regime when grinding largerubber parts that are used like coat for rollers in paper industry. In order to analyse the variation of workpiece temperature when finishing grinding of the rollers rubber coat a full factorial design of experiments was used considering the cutting parameters as independent variables. The proper selection of cutting conditions for the grinding of large rubber rolls should take into consideration the thermal regime and the workpiece temperature variation because it is well known that this material is extremely sensitive to high temperature exposure and that build-up of rubber on the face of the grinding wheel may occur. In the experiments, abundant flow of cutting fluids is used.
\end{abstract}

Keywords: Grinding rubber rolls; abundant cutting fluid flow rate; thermal regime; cutting parameters

\section{Introduction}

The heat generated by the cutting processes is a consequence of the material deformation, chips segmentation and removal, as well as of the friction between the chips and the tool and between the tool and the machined surface. The heat resulting from this main is shared by the tool, chips, blank and the environment.

Thermal phenomena, which inevitably accompany the grinding process of the rubber parts, has a significant influence on the workpiece accuracy and a smaller one on the cutting tool wear and the deformation process. Increased heat in the contact area between the grinding wheel and the machined surface can cause errors that can lead to grinding surface degradation (pinching, burns, cracks, cuts).

In printing and textile industry a wide variety of rollers are used with a steel core and an overlying rubber coating. The main industrial application of this rollers are printing and deflection processes. The surface quality, roundness and concentricity accuracy that are required are in the range of a few hundredths of a millimetre. This level of precision is typically achieved by external cylindrical grinding. processes.

In the case of the rubber grinding processes, it is recommended that the temperature in the cutting area to not exceed a limit of $15^{\circ} \mathrm{C}$ and that an abundant cutting fluid flow rate $(80-1001 / \mathrm{min})$ to be used. Also, the scientific literature [1, 2 , 3] recommends that for every $10 \mathrm{~mm}$ of the abrasive wheel height is useful to provide a cooling fluid flow rate of $5 . .8$ $1 / \mathrm{min}$. The higher the hardness of the abrasive material used is and the denser the wheel structure is, a higher cutting fluid 
flow rate must be used. In order to improve the quality of the coolant it is necessary to introduce certain additives, as well as the elimination of the impurities using the filters and separators.

Taking into account the above considerations, the rigorous control of the temperature developed in the cutting area is required for the grinding of the hard rubber parts. The cutting parameters must be carefully chosen as to ensure during the cutting process, in the contact area between the grinding wheel and the rubber workpiece, temperatures lower than the rubber thermal degradation temperature.

\section{Literature review}

The grinding process is the high temperature characterized by arising in zone of the cutting, promoting appearance heat defect on processed surface, reducing working factors of the details [18]. There is poor scientific literature on the grinding processes of the rubber rollers used in the paper industry. Most of the scientific work in this field[4, 5] deals with the machinability by grinding of the parts used in metallurgy and paper industry. The rubber covered rollers used in the paper industry are subjects of special inspections due to the demanding precision required in terms of surface finishing, roundness, concentricity, static and dynamic balance $[4,20]$

The literature review of the cutting processes of rubber parts deals mainly with the turning process of small dimension parts [6]. The grinding processes of the large rollers covered by hard rubber (usually 85-92 Shore) are poor documented in the scientific literature. Ștețiu [3] presents aspects of the choice of grinding wheels, abrasive liquids, especially for difficult grinding materials such as rubber, cork, felt, skin, wood, asbestos, and heat-sensitive materials - such as stainless steels, high-alloy steels. Also, firms that are specialized in machining parts for the paper industry give some technical recommendations and manufacturing solutions for grinding rubber rollers [4, 20, 21]

\section{Identify the problem}

The purpose of the research is to identify the problems that occur in the case of hard rubber grinding, in order to issue reliable technical solutions for avoiding thermal machining errors when grinding rubber covered rollers for the paper industry. In order to avoid thermal deformations an adequate thermal regime in the cutting area during the grinding process must be maintained.

The main technological objectives that must be considered when rough grinding rubber parts are obtaining the prescribed roughness, assuring the integrity of the machined surfaces (avoiding burns, cracks, pinching, scratches, and residual stresses) and the prescribed geometrical and shape precision. Rubber is being considered a highly thermal sensitive material for mechanical machining.Precision grinding processes for rubber rollers depends on a number of factors like machine stiftness, genmetrical and cinematical precision, tool type and precision, cutting conditions, etc One of the main factors that can aaffect the grinding process of rubber rollers precision is the thermal regime durring cutting.

Grinding of rubber is considered a difficult process, because of the build-up of rubber chips on the face of the grinding wheel and because of the thermal deformations of the part as a result of the cutting heat generated. Also, the friction generated by the abrasive wheel- rubber part contact, as the wheel cuts, combined with the poor thermal conductivity of rubber, leads to excessive heat generation. This can lead to wheel cracking and sometimes even breakage. For this reasons, the abrasive industry has often been hesitant to supply grinding wheels for this particular application.

The paper deals with optimizing the cutting parameters of the grinding process of large dimension hard rubber covered rolls with different or unburned sleeves with porous abrasive wheels. If the rubber covered rollers have not been properly grinding (resulting a crown deflections of $\mathrm{k}=1,420 \mathrm{~mm}$ on the rubber sheath rollers, $\Phi=800 \mathrm{~mm}$, see Figures 1 ) then the laminate strip breaks and the whole technological process is affected.

\section{Crown deflection}

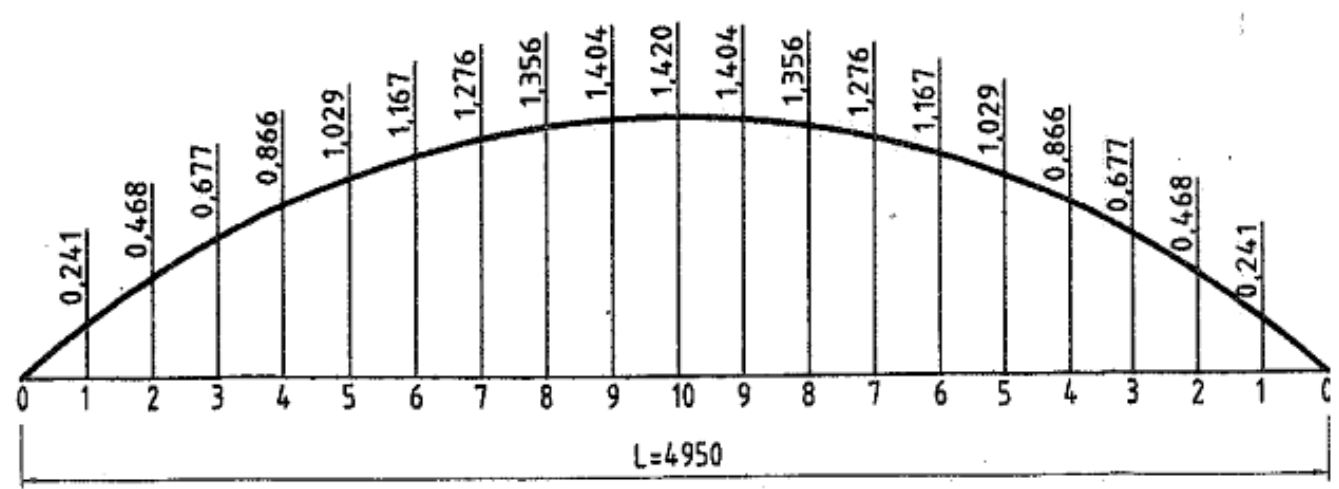

Fig. 1. The rubber rollers crown deflection, $\mathrm{k}=1,420 \mathrm{~mm}$ 


\section{The thermal regime of rubber grinding}

The manufacturing process grinding is characterized by high thermal loads caused by large contact areas and a high number of grain cuts as well as negative chip angle [19]. For the study of the thermal regime of the rubber grinding process, the infrared thermography method was used. This method consists in the remote detection of infrared radiation emitted by a product under examination and the transformation of the information gathered by point-to-point scanning into a visible image on which temperatures can be highlighted at any point. (See Figures 2, 3 and 4).

A thermovision camera, model FLIR type E-45 from Vrancart Adjud company from Romania was used.

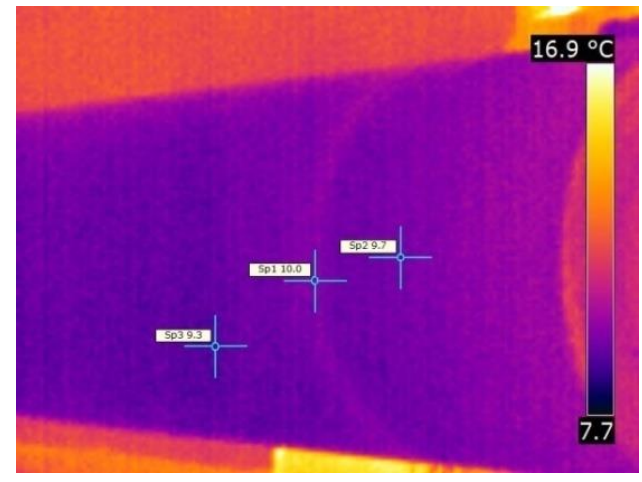

Fig. 2. Workpiece temperature measurement with FLIR E 45

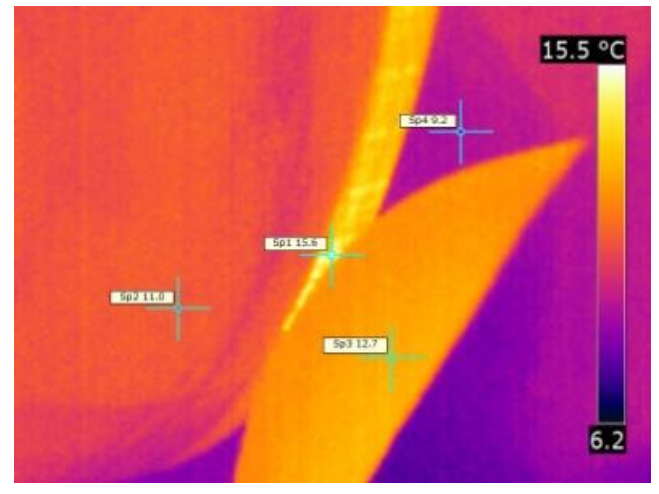

Fig. 3. Temperature measured with the FLIR - E 45 thermographic camera at short cooling fluid interruption

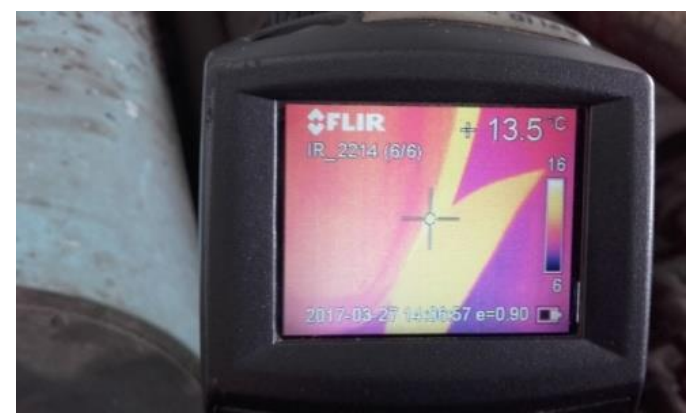

Fig. 4. Temperature measuring with the FLIR-E45 thermographic camera

\section{Experimental method}

Taking into account the recommendations from technical literature [7-11] and the cinematic possibilities of the Mockba Model XH-193H8 Grinding Roll Machine from the Mechanical Workshop ofVrancart Company, Adjud, Vrancea, (See Figures 6 and 7) the experiments were carried out by modifying the depth of cuta $[\mathrm{mm}]$, the longitudinal feed rate $f_{l}[\mathrm{~mm} / \mathrm{min}]$ and the workpiece speed (roller speed) $v_{p}[\mathrm{~m} / \mathrm{s}]$. The chosen values for these machining parameters are shown in Table 1.

The experiments were carried out with the purpose to draw some pertinent conclusions about the optimal cutting parameters for grinding large rubber rollers in terms of thermal cutting regime.

\begin{tabular}{|c|c|c|}
\hline \multicolumn{3}{|l|}{$\begin{array}{l}\text { Machine-tools: the Mockba model XH- } 193 \mathrm{H} 8 \text { grinding roll machine [10] } \\
\text { Abrasive wheel: Super-porous stone } 600 \times 304,5 \times 80 \\
(\mathrm{D} \times \mathrm{d} \text { x H), H [12] }\end{array}$} \\
\hline Cutting parameters & Values & U.M. \\
\hline Depth of processing $a_{p}$ & 0,$025 ; 0,100$ & {$[\mathrm{~mm}]$} \\
\hline Longitudinal feed $\mathrm{f}_{1}$ & $111 ; 250$ & {$[\mathrm{~mm} / \mathrm{min}]$} \\
\hline The speed of workpiece, $v_{p}$ & 0,$33 ; 0,55$ & {$[\mathrm{~m} / \mathrm{s}]$} \\
\hline $\begin{array}{l}\text { Observations: } \\
\text { - the grinder operations were done with coolant } \\
\text { (See Figures } 6 \text { and } 7 \text { ) }\end{array}$ & & \\
\hline
\end{tabular}

Table 1. The grinding conditiones 


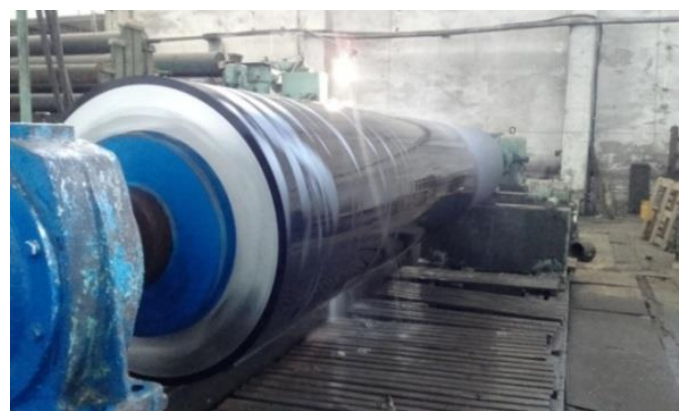

Fig. 5. Rubber rollers grinding process using abundant cooling liquid at SC Vrancart SA Adjud, Vrancea

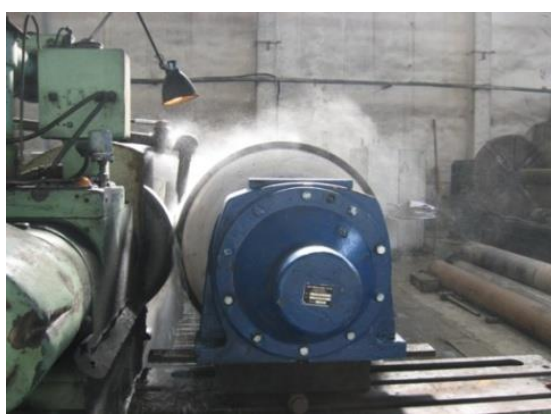

Fig. 6. Front view of the rubber rollers grinding process

Super porous abrasives wheels are successfully used for the process of grinding rubber rollers used for the paper industry $[4,12]$. The super porous abrasive wheels with the following dimensions: $600 \times 304,5 \times 80(\mathrm{D} \mathrm{x} \mathrm{d} \mathrm{x} \mathrm{H})$ and the hardness $\mathrm{H}$ were used on the grinding machine XШ-193H8 Mosckba for grinding of large rubber rollers. The grinding wheels used were: $33 \mathrm{~A} 46 \mathrm{~J} 10 \mathrm{~V}$ for roughing and $22 \mathrm{C} 80 \mathrm{~J} 10 \mathrm{~V}$ for finishing.

We mention that the same types of abrasive wheels are used for the grinding of rubber parts in other paper factories than the one where the research have been done, for example SC Ambro SA Suceava and SC Ecopaper SRL Zărnești (See Figures 8 and 9).

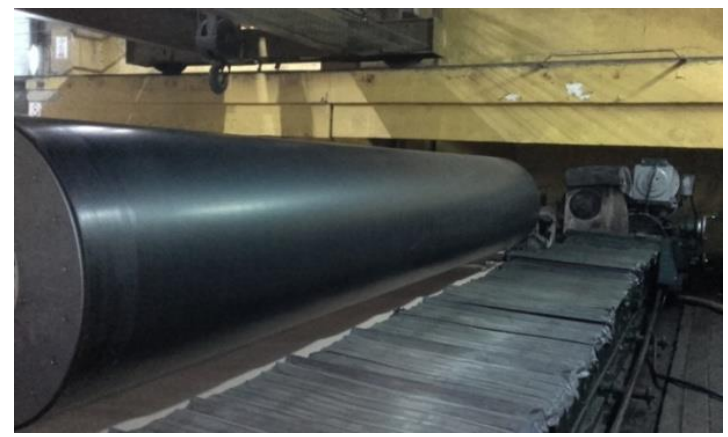

Fig. 7. Grinding of rubber roller at SC Ambro SA Suceava

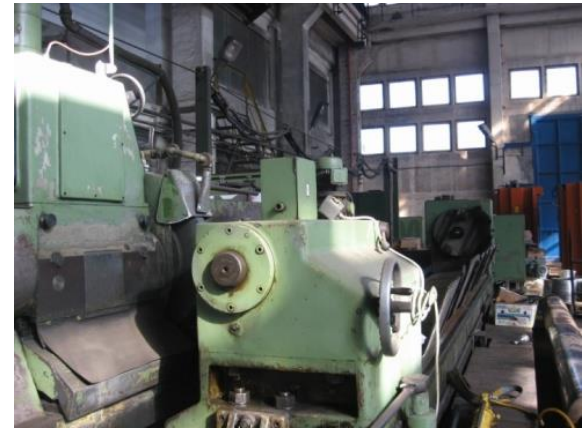

Fig. 8. Grinding machine at SC Ecopaper SRL Zarnesti

\section{Design of experiments - DOE}

Design of experiments (DOE) is an important statistical technique for improving product quality and solving production problems.

The plan chosen for the experiments is shown in Table 3.

\begin{tabular}{|c|c|c|c|}
\hline \multirow{2}{*}{$\begin{array}{c}\text { Experiment } \\
\text { number }\end{array}$} & \begin{tabular}{c}
$|c|$ \\
\cline { 2 - 3 } \\
workpiece \\
of \\
$\mathbf{v}_{\mathbf{p}}[\mathbf{m} / \mathbf{s}]$
\end{tabular} & $\begin{array}{c}\text { Longitudinal } \\
\text { cutting feed } \\
\mathbf{f}_{\mathbf{l}}[\mathbf{m m}]\end{array}$ & $\begin{array}{c}\text { Depth of } \\
\text { cut } \\
\mathbf{a}_{\mathbf{p}}[\mathbf{m m}]\end{array}$ \\
\hline 1. & +1 & +1 & +1 \\
\hline 2. & +1 & +1 & -1 \\
\hline 3. & +1 & -1 & +1 \\
\hline 4. & +1 & -1 & -1 \\
\hline 5. & -1 & +1 & +1 \\
\hline 6. & -1 & +1 & -1 \\
\hline 7. & -1 & -1 & +1 \\
\hline 8. & -1 & -1 & -1 \\
\hline
\end{tabular}

Table 2. Standard $2^{3}$ full factorial design matrix

In this paper, three input independent variables and two levels $(-1)$ and $(+1)$ were chosen for the variance of the parameters and the prediction of the optimal values, as shown in Table 2 . The symbolization used was: $(-1)$ for the lower level of a factor; (+1) for the upper level of a factor. According to this convention, the matrix of experiences can be written, Table 3 and 4. 


\begin{tabular}{|c|c|c|c|}
\hline Factor & $\mathbf{v}_{\mathbf{p}}[\mathbf{m} / \mathbf{s}]$ & $\mathbf{f i}_{\mathbf{i}}[\mathbf{m m} / \mathbf{m i n}]$ & $\mathbf{a p}_{\mathbf{p}}[\mathbf{m m}]$ \\
\hline NivelLevel & & & \\
\hline-1 & 0,33 & 111 & 0,025 \\
\hline+1 & 0,55 & 250 & 0,100 \\
\hline
\end{tabular}

Table 3. Selection of the independent variables and their levels

\section{Workpiece temperature analysis during grinding}

In the development of the present research it was considered necessity to determine the correlation between the cutting parameters: the workpiece speed $\mathrm{v}_{\mathrm{p}}[\mathrm{m} / \mathrm{s}]$, the longitudinal feed $\mathrm{f}_{1}[\mathrm{~mm} / \mathrm{min}]$ and the depth of cut $\mathrm{a}_{\mathrm{p}}[\mathrm{mm}]$ over the part temperature. For the workpiece temperature, a regression function was determined with a form of polytrophic equation [13]:

$$
\mathrm{T}=\mathrm{C}_{\mathrm{T}} \mathrm{v}_{\mathrm{p}}^{\alpha} \mathrm{f}_{\mathrm{l}}^{\beta} \mathrm{a}_{\mathrm{p}}^{\gamma}
$$

Another indicator of a good cooling in the grinding process is the temperature of the liquid after the process: the lower the liquid temperature is, the cooling is considered to be optimal [3].

The cutting liquid that is most commonly used is the aqueous solution with small amount of soda ash, soap. When finishing grinding, the cutting fluid chemical composition may influence the surface quality. It is recommended to keep a clean coolant during machining. The washing capacity of the coolant influences the finishing grinding; in this sense it is recommended to use liquids having a high washing capacity. [14-17] $2^{3}=8$ full factorial experiments plan was performed.

\begin{tabular}{|c|c|c|c|c|}
\hline \multirow{2}{*}{$\begin{array}{c}\text { Exp. } \\
\text { num.r }\end{array}$} & $\begin{array}{c}\text { The speed } \\
\text { of } \\
\text { workpiece } \\
\mathbf{v}_{\mathbf{p}}[\mathbf{m} / \mathbf{s}]\end{array}$ & $\begin{array}{c}\text { Longitudinal } \\
\text { cutting feed } \\
\mathbf{f}[\mathbf{m m} / \mathbf{m i n}]\end{array}$ & $\begin{array}{c}\text { Depth of } \\
\text { cut } \\
\mathbf{a}_{\mathbf{p}}[\mathbf{m m}]\end{array}$ & \\
\hline 1. & 0,50 & 250 & 0,100 & 12 \\
\hline 2. & 0,50 & 250 & 0,025 & 11 \\
\hline 3. & 0,50 & 111 & 0,100 & 10,5 \\
\hline 4. & 0,50 & 111 & 0,025 & 10 \\
\hline 5. & 0,33 & 250 & 0,100 & 9,8 \\
\hline 6. & 0,33 & 250 & 0,025 & 9,6 \\
\hline 7. & 0,33 & 111 & 0,100 & 9,5 \\
\hline 8. & 0,33 & 111 & 0,025 & 9 \\
\hline
\end{tabular}

Table 4. Experimental plan with assign parameters and response values

For the considered regression equation: $\mathrm{T}=\mathrm{f}\left(\mathrm{v}_{\mathrm{p}}, \mathrm{f}_{\mathrm{l}}, \mathrm{a}_{\mathrm{p}}\right)$, after the experiments were carried out the experimental data was processed with a specialized software, MINITAB 17 free version. For the experimental values obtained, the software returned the following temperature variation law (regression equation):

$$
\mathrm{T}=8,3903 \times \mathrm{v}_{\mathrm{p}}{ }^{0,27352} \times \mathrm{f}_{\mathrm{l}}{ }^{0,105955} \times \mathrm{a}_{\mathrm{p}}{ }^{0,03992}
$$

As we can see, the influence of the workpiece speed had manifested a higher influence on the workpiece temperature compared to the longitudinal cutting feed and the cutting depth.

With the software MINITAB 17 free version, the workpiece temperature variation with the longitudinal cutting feed $\mathrm{f}[\mathrm{mm} / \mathrm{min}]$ and the cutting depth $[\mathrm{mm}]$ graph was plotted (See Figure 10). There can be observed a rise in temperature with the increase of the cutting depth and the longitudinal cutting feed.

Figure 11 shows the variation of the temperature in relation with the workpiece speed $\mathrm{v}_{\mathrm{p}}[\mathrm{m} / \mathrm{s}]$ and the longitudinal cutting feed $f_{l}[\mathrm{~mm} / \mathrm{min}]$. An increase in workpiece temperature can be observed with the increase of the workpiece speed $v_{p}[\mathrm{~m} / \mathrm{s}]$ and the longitudinal feed rate $\mathrm{f}_{1}[\mathrm{~mm} / \mathrm{min}]$. As we can see the cutting speed exercises a higher influence over the workpiece temperature.

Figure 12 shows the temperature variation according to the workpiece speed $\mathrm{v}_{\mathrm{p}}[\mathrm{m} / \mathrm{s}$ ] and the cutting depth [mm]. There can be observed an increase in temperature with the workpiece speed increase and the workpiece depth [mm] increase. 


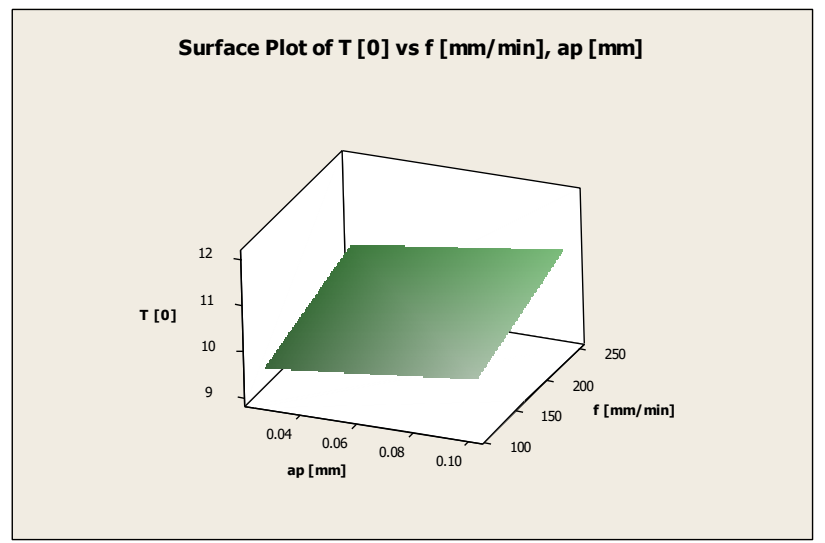

Fig. 9. 3D surface plot for effect of longitudinal cutting feed $\mathrm{f}_{1}[\mathrm{~mm} / \mathrm{min}]$ and depth of cut $\mathrm{a}_{\mathrm{p}}[\mathrm{mm}]$ on workpiece temperature $\mathrm{T}\left[{ }^{0} \mathrm{C}\right]$

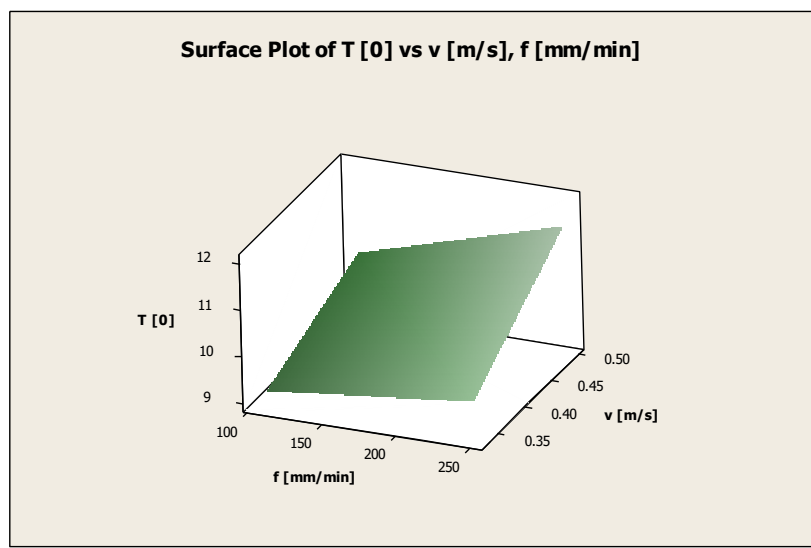

Fig. 10. Surface plot of $\mathrm{T}\left[{ }^{0} \mathrm{C}\right]$ versus workpiece speed vp $[\mathrm{m} / \mathrm{s}]$, longitudinal advance $\mathrm{fl}[\mathrm{mm} / \mathrm{min}]$

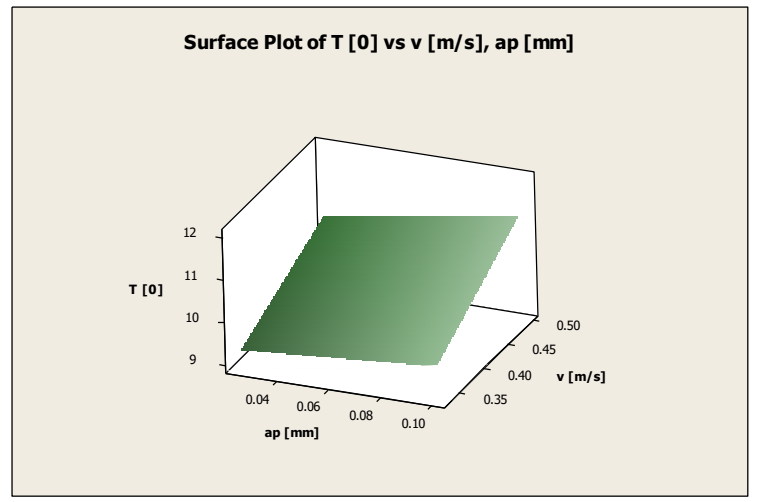

Fig. 11. 3D surface plot for effect of workpiece $\operatorname{speedv}_{\mathrm{p}}[\mathrm{m} / \mathrm{s}]$ and depth of cut $\mathrm{a}_{\mathrm{p}}[\mathrm{mm}]$ on workpiecetemperature $\mathrm{T}\left[{ }^{0} \mathrm{C}\right]$

Figure 13 and 14 show the factors main effects and factors interactions on the workpiece temperature variation. The three input parameters chosen for the study have a negative influence on the workpiece temperature during grinding. The main effects plot gives the optimal combination of grinding process parameters for minimal workpiece temperature during machining. The optimal combination of parameters is found to be $\left(v_{p}-(-1), f_{l}-(-1), a_{p}-(-1)\right)$, lower-levels of workpiece speed, feed rate and depth of cut. Also, the main effect plot throws some light on the significance of the parameters on the system response. The slope of the main effect plot for each parameter reveals the intensity of the influence of the parameter. The plot having higher inclination will have higher influence. From Figure 13, it can be observed that the factor workpiece speed is more significant while the factor depth of cut has the lowest significance.

Interactions between the parameters were studied by using interaction plot drawn and shown in Figure 14. As expected, the interaction between worpiece cutting speed and the longitudinal cutting feed has the greatest influence over the workpiece temperature during grinding.

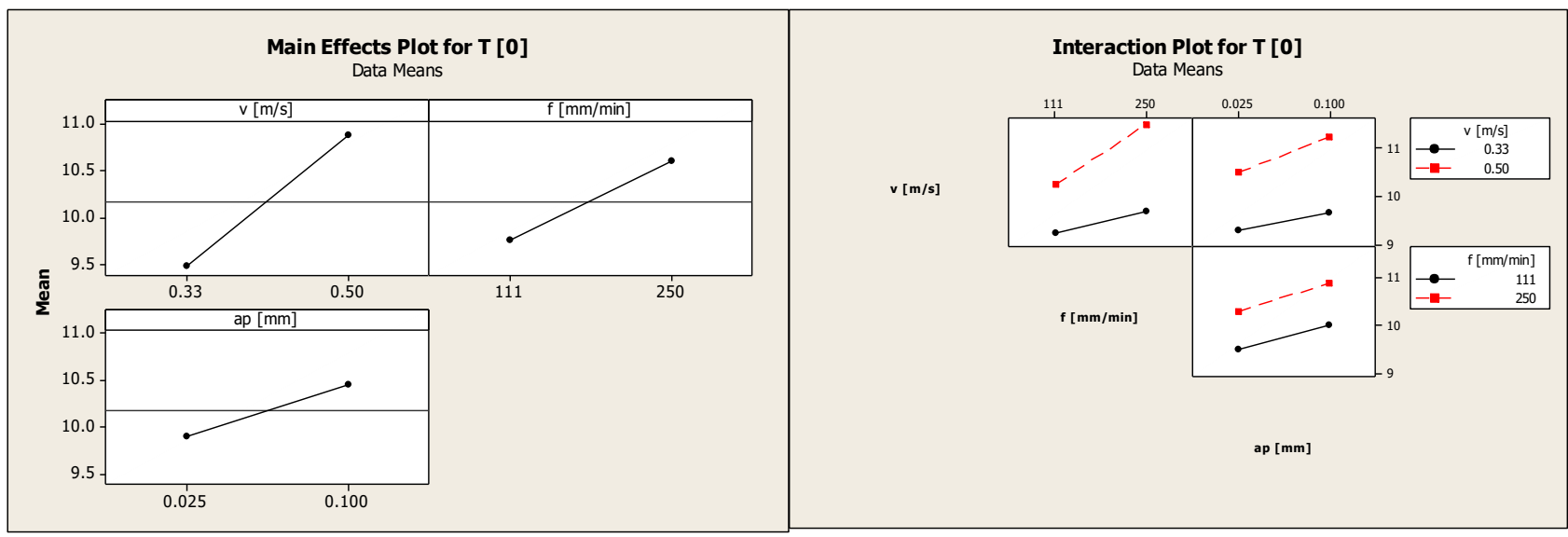

Fig.12. Main effects plot for $\mathrm{T}^{0} \mathrm{C}$

Fig. 13. Interaction plot for $\mathrm{T}^{0} \mathrm{C}$. 


\section{Regresion analysis}

The Minitab out put for the regression is presented below:

Equation

$\mathrm{T}[\mathrm{C}]=8.3903 * \operatorname{vp}[\mathrm{m} / \mathrm{s}]^{\prime} \wedge 0.27352 *$ 'fl $[\mathrm{mm} / \mathrm{min}]^{\prime} \wedge 0.105955 *$ 'ap [mm]' ^ 0.0399203

Parameter Estimates

Parameter Estimate SE Estimate 95\% CI

$\begin{array}{llll}\mathrm{c}_{\mathrm{T}} & 8.39030 & 1.21337 \quad(5.61102,12.4962)\end{array}$

$\begin{array}{llll}\alpha & 0.27352 & 0.04128 & (0.15928,0.3887)\end{array}$

$\begin{array}{llll}\beta & 0.10596 & 0.02581 & (0.03440,0.1779)\end{array}$

$\begin{array}{llll}\gamma & 0.03992 & 0.01509 & (-0.00193,0.0819)\end{array}$

$\mathrm{T}[\mathrm{C}]=\mathrm{c}_{\mathrm{T}}{ }^{\prime} \operatorname{vp}[\mathrm{m} / \mathrm{s}]^{\prime \wedge} \alpha * ' \mathrm{fl}[\mathrm{mm} / \mathrm{min}]^{\prime \wedge} \beta *$ ap $[\mathrm{mm}]^{\prime \wedge} \gamma$

Summary

Iterations 6

Final SSE 0.363791

DFE 4

MSE $\quad 0.0909479$

$\mathrm{S} \quad 0.301576$

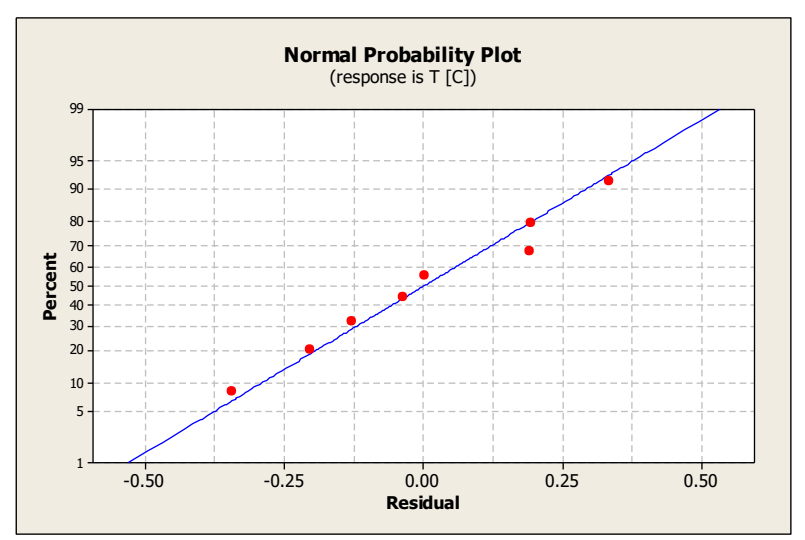

Fig. 14. Normal probability plot for T [C]

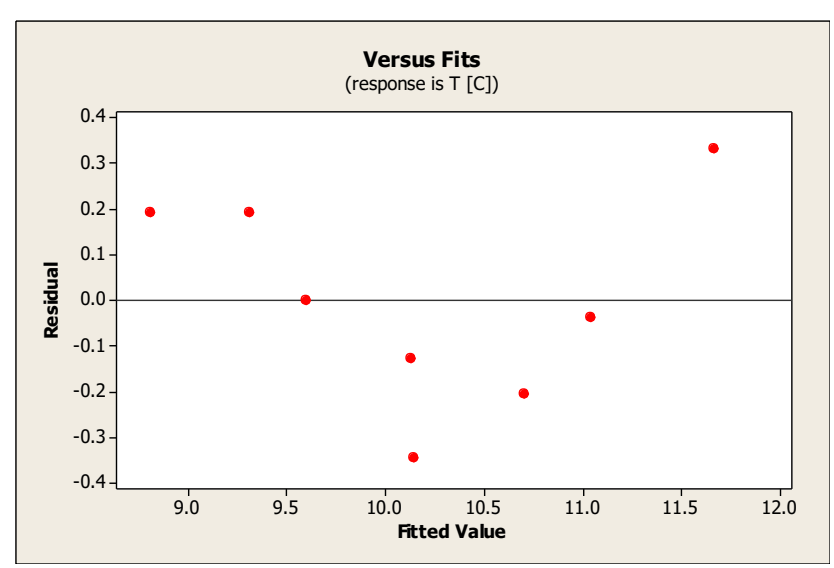

Fig. 15. Residuals versus the fits plot for T [C]

In the section Parameter Estimates there are given the points estimated for the parameters and the $95 \%$ confidence intervals. We consider this to be a reasonable range that implies significance.

The value 0.301576 for the Standard error of the regression S indicates that the observed temperature values fall a standard distance (roughly an average absolute distance) of 0.301576 units from the fitted mobility values determined with the regression equation.

The normal probability plot shows an approximately linear pattern consistent with a normal distribution. (See Figure 15) The plot of residuals versus the fitted values shows a random pattern, which suggests that the residuals have constant variance. (See Figure 16)

Therefore, the regression equation obtained "(2)" can be consider adequate for analyzing the thermal regime of the rubber workpiece during grinding with abundant cutting fluid flow rate. The regression model specify correctly the relationship between the response-workpiece temperature and the predictors - workpiece speed, longitudinal cutting feed $\mathrm{f}[\mathrm{mm} / \mathrm{min}]$ and the cutting depth [mm].

According to the regression equation obtained, the optimal conditions that can assure a minimal workpiece temperature during grinding and therefore smaller thermal deflection of the rubber rollers machined with abundant lubricant flow rate (100 l / min), imply using smaller values for the cutting parameters, especially for the workpiece speed $\mathrm{v}_{\mathrm{p}}[\mathrm{m} / \mathrm{s}]$.

\section{Conclusion}

This paper purpose was to investigate the influence of cutting conditions over the workpiece temperature durring rubber rollers grinding process. The process thermal regim and esspecialy the workpiece temperature has a significant influence over the grinding process ability to produce the round, concentric rubber rolls with tight tolerances and free from surface inconsistencies and variations. High cutting temperature can lead to thermal deflections that result in crown shaped external diameter rollers. 
That is why it is very important to analyse and prevent temperaturevariations on the roll face durring machining. By analyzing the measured temperatures of the workpiece (that were in the range of $9-12^{\circ} \mathrm{C}$ ) during the grinding tests that were carried out it was found that the abundant lubricant flow rate $(1001 / \mathrm{min})$ can limit and eliminate much of the amount of heat released in the cutting zone.

For the specific cutting conditions used in the experiments, the surface quality obtainedwas the one prescribed and no burn, cracks or other defects could be observed on the machined surfaces. It has also been found that the influence of the workpiece (the roller) speed manifests a greater influence over the workpiece temperature during grinding, compared to the longitudinal cutting feed and the cutting depth.

Since the grinding process of rubber parts is a difficult industrial application (because of the thermal sensitivity of the machined material), it is necessary to continue the researches with higher cutting speeds and even high flow rates for the cutting coolant, or using different cooling methods in order to establish the proper conditions necessary for grinding rubber covered rollers with high productivity and accuracy .

Also, as a further research direction, it is proposed to continue the grinding of hard rubberin a cryogenic medium (liquid nitrogen) with higher cutting speeds with the purpose of increasing process productivity.

\section{References}

[1] Vlase, A. \&Gheorghiu, S.,(1995). Processing technologies on grinding machines, Technical Publishing House,ISBN 973-31-0629-1, Bucharest, Romania

[2] Vlase, A., Bălan, I.R \&Vlase, B.G., (2011). Design of technologies on grinding machines, Printech PublishingHouse,ISBN 978-606-521-729-4, Bucharest, Romania

[3] Ștețiu, M., Lăzărescu, I.D., Oprean, C., \&Ștețiu, G., (1994). Theory and practice of cutting tools, vol. III, Design of cutting tools (II), University of Sibiu Publishing House, Sibiu, Romania

[4] Negrea, I \&Kaima, A., (1987) Abrasive bodies for grinding cylinders, Edited by Carbochim Cluj-Napoca, ClujNapoca, Romania

[5] Axinte, D.A., (1996), The correlation between the grinding process and the rolling mill grinding machine, PhDDissertation, University of Galati, Faculty of Mechanics, Galati, Romania

[6] Popescu, I., (1998). Research on cutting of non-ferrous and non-metallic materials), Reprography of the Universityof Craiova, Craiova, Romania

[7] Alexis, J., (1999). Taguchi Method in Industrial Practice - Experience Plans, Technical Publishing House, ISBN973-31-1352-2, Bucharest, Romania

[8] Muscă, G., Amarandei, D. \& Ionescu, R., (1998), Experimenting, modeling and optimizing products and processes, Technical Publishing House, Chisinau, Moldavia

[9] Ionescu, R. \&Amarandei, D., (2004). Experiment Planning - Efficiency and Quality,A.G.I.R.PublishingHouse,ISBN 973-8466-43-1, Bucharest, Romania

[10] ***Roller Grinding Machine Technical Paper model XШ-193H8, (1982). Mockba, URSS

[11] ***Grinding machines, (1982).Stankoimport, Moscou, URSS, 1982

[12] $* * *$ Catalog of abrasive products Carbochim, (2015). Cluj-Napoca, Romania

[13] Străjescu, E., (2004). The roughness of cutting tools, BrenPublishing House, ISBN 973-648-366-5, Bucharest, Romania

[14] Savin, I.M., (2006). Cooling - spray lubrication in metal cutting, PerformanticaPublishing House, ISBN 978-973730-321-9, Iasi, Romania,

[15] Bărbulescu, V., (1973). Rectifiers - Quality and quality control of machined parts by grinding, no.3, Ministry ofHeavy Machinery Construction, Office of Documentation and Technical Publications, Bucharest, Romania

[16] Ciolacu, F.G., (2006). Managing the technological fluids for cutting, SitechPublishing House, ISBN 973-746-3382, Craiova, Romania

[17] Ștefãnescu, I., (2011). Improved machinability by using fluids for cutting, SitechPublishing House, Craiova,ISBN 978-606-11-1873-1, Craiova, Romania

[18] Starshev, D. (2008), Influence of the mode of the cooling under grinding on quality of surface layer.(Report)" Annals of DAAAM \& Proceedings. DAAAM International Vienna.

[19] Schneider, M.; Klein, F. \& Abt, C. (2010), Reductionof coolinglubrificationsin the grinding process, 7th International DAAAM Baltic Conference

[20] Practical Roll Techniques: Grinding \& Balancing, Valmet technical paper series, september 2013, http://www.valmet.com/globalassets/media/downloads/white-papers/roll-services/wpr_grindandbalance.pdf, Accessed on: 2017-06-10

[21] The polishing of rubber covered rollers, Roller Manufacturing Articles, Rollertech, http://www.rollertech.co.uk/articles/polishing.html Accessed on: 2017-06-10 